\title{
Blockage of IGF-1R signaling sensitizes urinary bladder cancer cells to mito- mycin-mediated cytotoxicity
}

\author{
SUN Hong ZHI ${ }^{1, *}$, SHU FANG WU ${ }^{2, *}$, ZENG HoNG TU ${ }^{2, * *}$ \\ 1 Department of Biological Regulation, Weizmann Institute of Science, Rehovot 76100, Israel. Tel: 00972-8- \\ 9343182. E-mail: hongzhi@wicc.weizmann.ac.il 7nbsp; Fax: 00972-8-9344116
}

2 State Key Laboratory of Drug Research, Shanghai Institute of Materia Medica, Chinese Academy of Sciences, 294 Taiyuan Road, Shanghai 200031, China

\begin{abstract}
A major problem which is poorly understood in the management of bladder cancer is low sensitivity to chemotherapy and high recurrence after transurethral resection. Insulin-like growth factor 1 receptor (IGF$1 R$ ) signaling plays a very important role in progression, invasion and metastasis of bladder cancer cells. In this study, we investigated whether IGF-1R was involved in the growth stimulating activity and drug resistance of bladder cancer cells. The results showed: The mRNAs of IGF-1, IGF-2 and IGF-1R were strongly expressed in serum-free cultured T24 cell line, whereas normal urothelial cells did not express these factors/receptors or only in trace levels; T24 cell responded far better to growth stimulation by IGF-1 than did normal urothelial cells; blockage of IGF1R by antisense oligodeoxynucleotide (ODN) significantly inhibited the growth of T24 cell and enhanced sensitivity and apoptosis of T24 cells to mitomycin (MMC). These results suggested that blockage of IGF-IR signaling might potentially contribute to the treatment of bladder cancer cells which are insensitive to chemotherapy.
\end{abstract}

Key words: IGF-1R signaling, autocrine, drug resistance, apoptosis, transitional cell carcinoma.

\section{INTRODUCTION}

Transitional cell carcinoma (TCC) of the bladder represents the fifth most prevalent malignancy in western population. A major problem in the management of TCC is the low sensitivity to chemotherapy and the high recurrence after transurethral resection, which occupies a large proportion (approximately 40\%) among bladder cancer patients $[1,2]$. So drug resistance remains a major and difficult problem to resolve in TCC chemotherapy. This phenomenon has often been ascribed to some mechanisms, such as the overexpression of multidrug transporters P-glycoprotein, multidrug resistance related protein (MRP) and other variables closely implicated DNA repair and induction/

*These authors contributed equally to this work.

**Corresponding author, Tel: 0086-21-64311833-325, Fax: 008621-64370269, E-mail: zhtu@mail.shcnc.ac.cn

Received March-9-2001 Revised April-28-2001 Accepted May$8-2001$ modulation of apoptosis (such as p53 and the Bclprotein family[3-4]). Furthermore, it has been recently shown that certain growth factors (Insulinlike growth factors-IGFs, etc) might be involved in the mechanism of drug resistance[5]. Clearly, these findings suggest the design of new strategies might improve bladder cancer response to chemotherapy.

The insulin-like growth factor system is widely involved in human carcinogenesis[6]. The type 1 insulin-like growth factor receptor (IGF-1R) is a transmembrane protein tyrosine kinase which mediated the biological effects of IGF-1 and most of the actions of IGF-2[7]. It plays an important role in both normal and abnormal growth, particularly in anchorage independent growth. Impairment of its function caused apoptosis of some kinds of cancer cells and inhibition of tumor growth in experimental animals[8,9]. Some investigators also provided evidences that IGF-1R signaling might be 
implicated in the mechanism of drug resistance in human breast cancer and multiple myeloma[5,10, 11]. IGF-1R activation could afford drug protection either by affecting the negative regulators of the apoptosis pathway, Bcl-2 and Bcl-xl, or by altering activity of the ced-3/ICE-like proteases and [12-14] p53, the Bcl-protein family are now confirmed and prominent in the mechanism of drug resistance[15,16]. More recently, Huo et al demonstrated that IGF-1R system protected colon cancer cells from apoptosis induced by cytotoxic agents, this acquired drug resistance might be mediated by multiple mechanisms, including promoting expression of multidrug resistance gene (mdr-1 gene) etc[17]. Lowering IGF-1R system might thus represent an attractive strategy to be pursued for chemopreventive purpose.

Bladder cancer cells were found to overexpress high levels of functional IGF-1 receptors and IGF$2[18],[19]$. There were considerable evidences that the antiapoptotic function of IGF-1R signaling contributed to progression, invasion and metastasis of bladder cancer[20]. Therefore, the main objective of the present work is to elucidate (1) Is IGF-1 R signaling pathway involved in autocrine growth of human bladder cancer? (2) Whether IGF-1R is involved in the growth stimulating activity and drug resistance of bladder cancer cells? (3) Can targeting against IGF-1R gene significantly enhance drug sensitivity of urinary TCC to mitomycin, which is one of the most effective and popular drug used for its chemotherapy?

\section{MATERIALS AND METHODS}

\section{Cells culture}

T24 cells line, established from a high grade and invasive human urinary bladder cancer patient and usually used as a model for drug sensitivity studies [21], was kindly supplied by Shanghai Institute of Cell Biology, Chinese Academy of Sciences. The cells were maintained in RPMI 1640 (GIBCO-BRL), supplemented with $5 \%$ heat-inactivated fetal calf serum (FCS), $1 \%$ Lglutamine, $1 \%$ penicillin/streptomycin solution, which contained $10,000 \mathrm{U} / \mathrm{ml}$ penicillin $\mathrm{G}$ and $10 \mathrm{mg} / \mathrm{ml}$ streptomycin sulfate. Cells were grown as adherent cells in a humidified atmosphere at $37^{\circ} \mathrm{C}$ in $5 \% \mathrm{CO}_{2}$. NCI $\mathrm{H} 69$ (a small-cell lung cancer line), $\mathrm{K} 562$ (a human erythro-leukemia cell line) were maintained in vitro as T24 cells.

Primary cultured normal human urothelial transitional epithelial cells, were established from normal ureters (from donors for kidney transplatation) by methods described previously
[22,22]. Cells were grown in PRMI 1640 medium supplemented with $10 \% \mathrm{FCS}, 10 \mu \mathrm{M}$ non-essential amino acids (GIBCO-BRL), $2.7 \mathrm{mg} / \mathrm{ml}$ dextrose, $1 \mu \mathrm{g} / \mathrm{ml}$ hydrocortisone (Sigma, St. Louis, MO), $5 \mu \mathrm{g} / \mathrm{ml}$ transferrin, $10 \mu \mathrm{g} / \mathrm{ml}$ insulin, $10 \mathrm{ng} / \mathrm{ml}$ epidermal growth factor, $100 \mu \mathrm{g} / \mathrm{ml}$ streptomycin, and $100 \mathrm{U} / \mathrm{ml}$ penicillin (GIBCO-BRL) in a humidified atmosphere of $5 \% \mathrm{CO}_{2}$.

\section{$R T-P C R$}

Cells of different groups were harvested with trypsin/EDTA $(0.05 \% / 0.01 \mu \mathrm{M})$, centrifuged at 8000 r.p.m for $5 \mathrm{~min}$ (In experiment that the autocrine expression of IGF system mRNA was investigated in T24 cells, the cell culture medium was changed into serum-free medium in order to avoid the disturbance effect of other exogenous growth factor contained in the serum, which might lead the unprecise results.) The supernatants were discarded and T24 cells were washed twice with PBS. RNA from the various fresh cell pellets was immediately extracted with phenol and guanidinium thiocyanate (Tri-reagent, GIBCO BRL). Synthesis of cDNA were carried out with reverse transcriptase (MMLV, 0.1U/1 $\mu \mathrm{g}$ RNA, GIBCO): $500 \mathrm{ng}$ of total RNA were transcribed into single-stranded cDNA using the buffer of 50 $\mathrm{mM}$ Tris-HCl (pH 8.3), $75 \mathrm{mM} \mathrm{KCl,} 3 \mathrm{mM} \mathrm{MgCl}$, $10 \mathrm{mM}$ DTT, $50 \mathrm{ng} / \mu \mathrm{l}$ oligo-dT random primer C(Sigma CO. Louis, MO) and $0.5 \mathrm{mM}$ deoxynucleotide triphophates (dNTPs, GIBCO), incubated at $37^{\circ} \mathrm{C}$ for $1 \mathrm{~h}$. After inactivation at $95^{\circ} \mathrm{C}$ for $5 \mathrm{~min}, 100 \mathrm{ng}$ of the cDNA products were added to a PCR cocktail consisting 2 . $8 \mu \mathrm{M}$ corresponding primers of the indexes to be detected and $\beta$ actin; 800 pM dNTPs; 10 mM Tris-HCl, pH 8.3; 50 mM KCl; 1 $\mathrm{mM} \mathrm{MgCl}_{2}$ and 0.08 units/ $\mu \mathrm{l}$ of Thermus acquaticus polymerase (Sigma). All of the primer sequences used in the present study, PCR product sizes and PCR conditions are listed in Tab 1. Oligonucleotides specific to IGFs system mRNA were designed from known genomic and cDNA information[23-25].

Preliminary time course experiments were performed using known positive control cell lines for IGF-1(NCI H69), IGF-2(NCI H69), and IGF-1 receptor(K562) to determine the optimal number of cycles of PCR to which cDNA products should be coamplified, while still observing predicted exponential production of respective PCR products of interest (IGF-1, IGF-2, or IGF-1 receptor) and the internal control $\beta$-actin. PCR yields in the controls were plotted on semilogarithmic graphs to determine the appropriate cycle numbers to evaluate relative levels of expression. Experiments were carried out for 28-35 cycles to ensure a linear range. Because the quantity of amplified $\beta$-actin fragments is assmed to be proportional to the amount of initial mRNA template, a relative level of expression of IGF-1 receptor, IGF-1, and IGF-2 could be determined by normalizing IGF amounts with $\beta$-actin amounts, as determined by densitometry (Molecular Dynamics, ImageQuant Software. Sunyvale CA).

\section{MTT assay}

$150 \mu \mathrm{l}$ confluent cell culture was transferred to 96 -well plate and $25 \mu \mathrm{l}$ MTT solution was added [3-(4, 5-dime- thylthiazol-2yl)-2, 5-diphenyltetrazoliumbromide, $5 \mathrm{mg} / \mathrm{ml}$, Sigma]. The blue dye taken up by the cells after $4 \mathrm{~h}$ incubation was dissolved in DMSO (100 $\mu \mathrm{l} /$ well), and its optical density at $495 \mathrm{~nm}$ was read on an automated micropcroplate reader (Bio-Tec, Winooski, VT). 
Tab 1. The RT-PCR primer sequence, PCR conditions and the PCR product sizes

\begin{tabular}{|c|c|}
\hline Primer sequence (product sizes ) & PCR condition \\
\hline $\begin{array}{l}\text { Internal control: b-actin ( } 211 \mathrm{bp}) \\
\text { F:5' CCTCTATGCCAACACAGTGC 3' } \\
\text { R:5' GTACTCCTGCTTGCTGATCC 3' } \\
\text { IGF1 (413bp) }\end{array}$ & Same as coamplified IGF1 (or IGF2 or IGF1R) \\
\hline $\begin{array}{ll}\text { F:5’ } & \text { TCCTCGCATCTCTTCTACC } 3 \\
\text { R:5' } & \text { TGGCATGTCACTCTTCACT } 3\end{array}$ & $94{ }^{\circ} \mathrm{C} 1 \mathrm{~min}, 58^{\circ} \mathrm{C} 1 \mathrm{~min}, 72^{\circ} \mathrm{C} 5 \mathrm{~min}, 30$ cycles \\
\hline $\begin{array}{l}\text { IGF2(303bp) F:5’ GTGGCATCGTTGAGGAGT } 3{ }^{\prime} \\
\text { R:5' CTTGGGTGGGTAGAGCAATC } 3{ }^{\prime} \\
\text { IGF1R ( } 450 \mathrm{bp})\end{array}$ & $94{ }^{\circ} \mathrm{C} 1 \mathrm{~min}, 55^{\circ} \mathrm{C} 1 \mathrm{~min}, 72^{\circ} \mathrm{C} 5 \mathrm{~min}, 28$ cycles \\
\hline $\begin{array}{l}\text { F:5' TGGGGAATGGAGTGCTGTAT 3’ } \\
\text { R:5' CGGCCATCTGAATCATCTTG 3' }\end{array}$ & $94^{\circ} \mathrm{C} 1 \mathrm{~min}, 56^{\circ} \mathrm{C} 1 \mathrm{~min}, 72^{\circ} \mathrm{C} 5 \mathrm{~min}, 35$ cycles \\
\hline
\end{tabular}

Results of a preliminary study with the MTT assay showed that the absorption was directly proportional to the number of cells.

\section{Evaluation of apoptosis by Flow-cytometry}

Then attached cells were treated with trypsin-EDTA, pelleted together with floating cells, washed once with ice-cold PBS, and resuspended in a hypotonic fluorochrome solution containing propidium iodide $50 \mu \mathrm{g} / \mathrm{ml}$ in $0.1 \%$ sodium citrate plus $0.03 \%$ (v/ v) Nonidet P-40. After 30 min of incubation in this solution, the samples were filtered through nylon $40 \mathrm{~m} \mathrm{~m}$ mesh cloth, and their fluorescence was analyzed as single-parameter frequency histograms using a FACSort flow cytometry (Becton Dickinson, Mountain View, CA). Apoptosis was determined by evaluating the percentage of events accumulated in the subdiploid peak [26].

\section{Assay for inhibition of ${ }^{3} \mathrm{H}$-thymidine incorpo- ration}

T24 cells were plated in triplicate wells in 96-well microtest plates $\left(1 \times 10^{4}\right.$ cells/well), incubated overnight. After either IGF$1 \mathrm{R}$ antisense or sense ODN was added, the cells were pulsed with $2 \mu \mathrm{Ci}\left[{ }^{3} \mathrm{H}\right]$-thymidine/well, $(22 \mathrm{Ci} / \mathrm{mM}$, Shanghai Institute of Nuclear Sciences, Chinese Academy of Sciences). Cells were incubated for $24 \mathrm{~h}$, trypsinized, and harvested on strips of fiber glass filter paper with a multiple automated sample harvesters (BECKMAN). The radioactivity of each sample was measured in a liquid scintillation counter(BECKMAN).

Effect of antisense $O D N$ on IGF-1R gene expression, protein synthesis, and apoptosis of T24 urinary bladder cancer cells

Antisense strategy for depleting IGF-1R was described previously[27]. The sense sequence was 5' AAG TCT GGC TCC GGA GGA and the antisense sequence was 5, TCC TCC GGA GCC AGA CTT, they represent codon 2-7 of the prepropeptide, and can effectively decrease the numbers of IGF-1 receptors as shown previously.

T24 cells were grown in 5\% FCS medium to subconfluence and then incubated in medium containing antisense or sense ODN (added at intervals of $24 \mathrm{~h}$ ) alone or in combination with 0 . $2 \mu \mathrm{M}$ MMC (treated for $1 \mathrm{~h}$, then replaced by drug-free culture medium) for $72 \mathrm{~h}$, and were harvested for analysis.

For evaluation of antisense on IGF1R protein expression of T24, cells were transferred to microtubes and lysed in lysis buffer (PBS containing $1 \%$ nonidet P-40, $0.5 \%$ sodium deoxycholate, $0.1 \%$ SDS, $1 \mathrm{mM}$ phenylmethylsulfonyl fluoride, and $10 \mu \mathrm{g} / \mathrm{ml}$ aprotinin) for $30 \mathrm{~min}$ on ice and vortex every $10 \mathrm{~min}$, after washing with PBS. The clear supernatant was collected after centrifugation at $15,000 \mathrm{rpm}$ for 20 minat $4^{\circ} \mathrm{C}$. Protein concentration in the lysate was determined by the Bio-Rad Bradfordprotein assay kit (Hercules, CA). Fifty micrograms of protein were denatured and fractionated on a 7.5\% SDS-polyacrylamide gel. After electrophoresis, proteins were transferred to a nitrocellulose membrane (Hybond-C, Amersham). Filters were exposed $3 \mathrm{~h}$ at $4^{\circ} \mathrm{C}$ to a blocking solution (Tris buffered saline solution containing $5 \%$ non-fat dry milk and $0.05 \%$ Tween 20 ) followed by an overnight incubation with monoclonal antibody H7 (dilution 1:1000) (Santa Cruz Biotechology, INC) in blocking solution. Filters were washed three times and incubated with a horseradish peroxidase conjugated anti-mouse-IgG for $1 \mathrm{~h}$. After three washes, the filters were developed by the enhanced chemoluminescence detection method (ECL kit, Amersham ) and exposed to kodak X OMAI film.

The IGF1R gene expression and apoptosis assessed by RTPCR and flow cytometry were performed as mentioned above. And for electron microscopy, cultured monolayer cells were fixed with $1 \%$ glutaraldehyde for $1 \mathrm{~h}$ and then fixed in $2 \%$ osmium tetroxide also for $1 \mathrm{~h}$. Ultrathin sections were stained with uranyl acetate and lead citrate.

\section{Statistical analysis}

Statistical analysis was performed with Student's t test or Chi-square test, $\mathrm{P}<0.05$ was considered significant.

\section{RESULTS}

Autocrine expression of IGF-1, IGF-2 and IGF1 receptor $m R N A$ of T24 urinary TCC

To evaluate expression of IGF-1, IGF-2, and IGF-1R mRNA in urinary bladder cancer cells and primary normal urothelial cells, RT-PCR was performed on extracted mRNA aliquots from serum- 


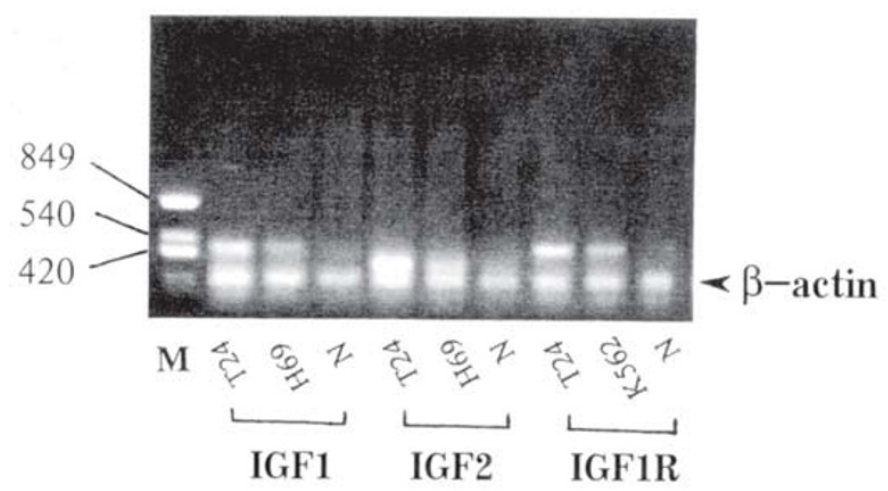

Fig 1. Analysis of IGF-1, IGF-2 and IGF1R mRNA levels by RT-PCR Coamplification of IGF-1 (413 bp), IGF-2 (303 bp) or IGF-1R (450 bp) with $\beta$-actin ( $211 \mathrm{bp}$ ). RT-PCR products were analyzed on ethidium bromide-stained agarose gels. Bands were examined by scanning densitometry. NCI H69, K562 cells were used as respective positive control. N: normal urothelial cells; M: marker (bp).

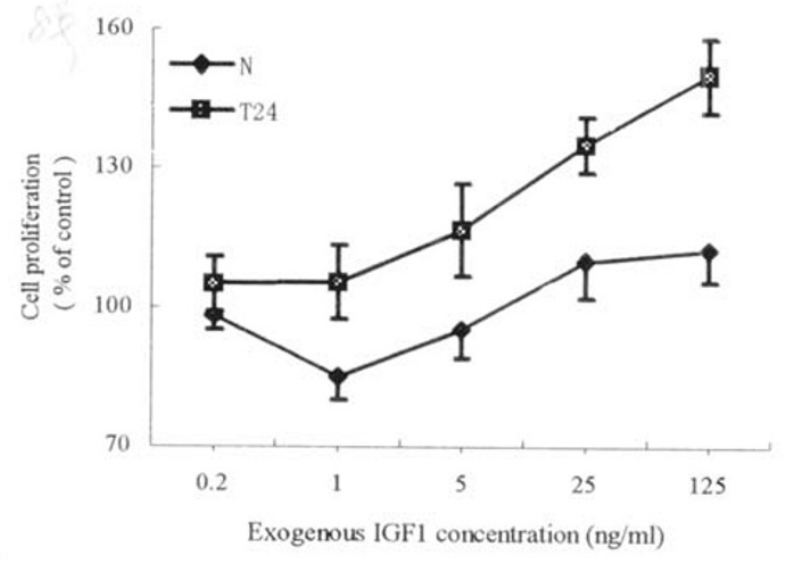

Fig 2. Effect of exogenous IGF1 on the growth of TCC and normal urothelial cells Results are expressed as percentage of IGF1-untreated controls. The results represent the mean \pm standard deviation of a representative experiment performed in triplicate. N: normal urothelial cells.

free cultured cells. T24 bladder carcinoma cells tested strongly expressed IGF-1, IGF-2, IGF-1R mRNAs (Fig 1). In contrast, IGF-1, IGF-2, IGF$1 \mathrm{R}$ mRNA were not expressed or expressed only at trace level by normal urothelial cells. Expression of $\beta$-actin was used as an internal control. $\beta$-actin remained stable in each group.

Effect of exogenous IGF-1 on T24 bladder cancer cells and primary cultured normal urothelial cells

For examination of effect of exogenous IGF-1 on the growth of TCCs and normal urothelial cells,

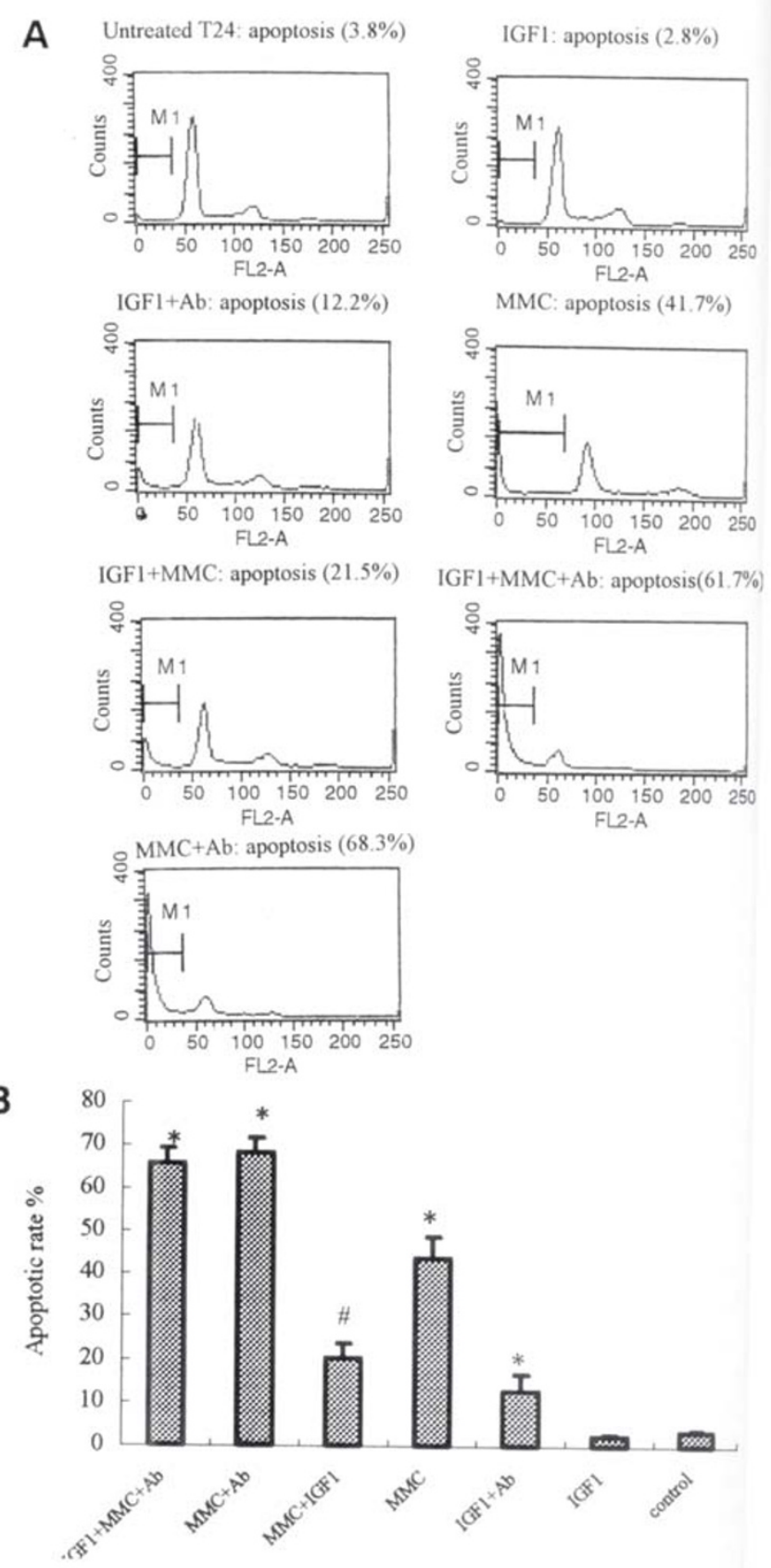

Fig 3. (A)Representative example of flow cytometric apoptosis analysis of T24 cells treated with MMC $(3 \mu \mathrm{M})$, IGF1 $(25 \mu \mathrm{g} / \mathrm{ml})$ or anti-IGF1R monoclonal antibody H7 (100 nM) or their combination. Propidium iodide-stained nuclei from apoptotic cells appear under the horizontal bars, and their percentages are indicated in each histogram. (B)Antiapoptotic effect of IGF1 on T24 cells. The results represent mean \pm standard deviation of a representative experiment performed in triplicate. The concentration of IGF 1 was $25 \mathrm{ng} / \mathrm{ml}$; the concentration of MMC was $3 \mu \mathrm{M}$; Ab: anti-IGF1R monoclonal antibody, used at the concentration of $100 \mathrm{n} \mathrm{M} .{ }^{\#} \mathrm{P}<0.05$ as compared with control ${ }^{*} \mathrm{P}$ $<0.05$ as compared with MMC group 
IGF-1 was added to individual wells at final concentrations of $0.2,1,5,25,125 \mathrm{ng} / \mathrm{ml}$. Although exogenous IGF-1 stimulated the growth of T24 and normal urothelial cells in a dose-dependent manner, T24 cells responded to IGF-1 significantly better than did the normal urothelial cells when $25 \mathrm{ng} /$ $\mathrm{ml}, 125 \mathrm{ng} / \mathrm{ml}$ was added (Fig 2).

Representative example and apoptotic value of flow cytometric analysis of T24 cells treated with 3 $\mu \mathrm{M}$ MMC, IGF-1, anti-IGF1R antibody or their combinations are shown in Fig 3A and Fig 3B. It has been known that the addition of MMC $(3 \mu \mathrm{M})$ to T24 cells can induce cell apoptosis[28,29]. In the present study, treatment of T24 cells with IGF-1 $(25 \mu \mathrm{g} / \mathrm{ml})$ significantly protected cells from apoptosis induced by MMC (MMC concentration used here was $3 \mu \mathrm{M}$, which was far higher than concentration

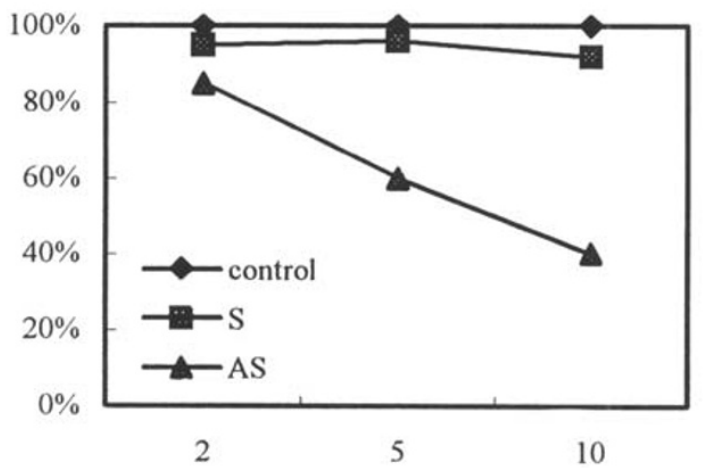

A Concentration of antisense ODN $(\mu \mathrm{M})$

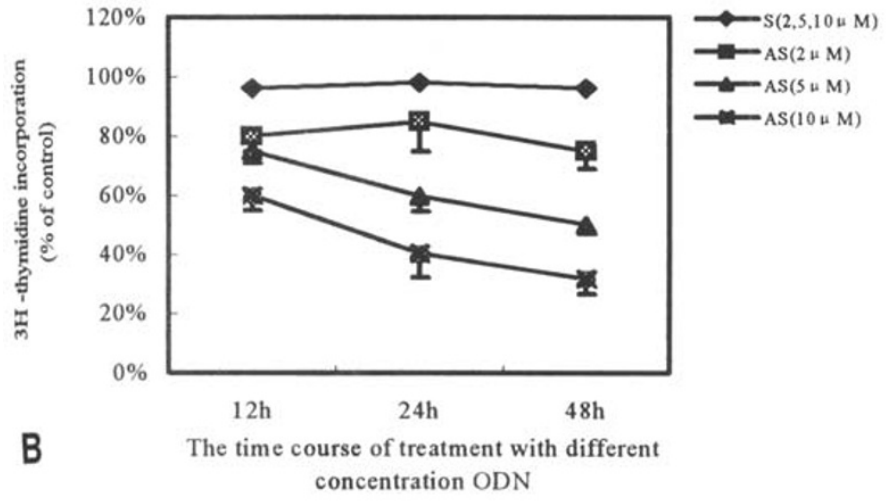

Fig 4. Effects of IGF1R antisense and sense ODN on ${ }^{3} \mathrm{H}$ thymidine incorporation of T24 cells (A) Dose-response curves after $24 \mathrm{~h}$ treatment. (B) Time courses of treatments with different concentration of oligonucleotides. The percentages of $3 \mathrm{H}$ thymidine incorporation of the treated samples were calculated against untreated cells. Three independent experiments each done in triplicate were performed to obtain means and SD. $\mathrm{S}$, sense; $\mathrm{AS}$, antisense. added in ODN experiment, see Fig 7). However, blocking of IGF1R signaling by anti-IGF1R antibody which inhibited the binding of either IGF-1 or IGF-2 to IGF-1R, the apoptotic rate induced by MMC restored to a higher level. This finding demonstrated that the addition of IGF-1 significantly potentiated the resistance of T24 bladder cancer cells to MMC and mimicked those observed by T24secreted IGF1.

Inhibition of T24 cell proliferation by IGF1R antisense ODN

Proliferation of human bladder cancer cells was dramatically inhibited by IGF-1R antisense ODN treatment (Fig 4). The inhibition by IGF-1R antisense ODN was dose- and time-dependent. Significant inhibition occurred at $24 \mathrm{~h}$ after application of $5 \mathrm{mM}$ IGF-1R antisense ODN and at $12 \mathrm{~h}$ after application of $10 \mathrm{mM}$ IGF-1R antisense ODN.
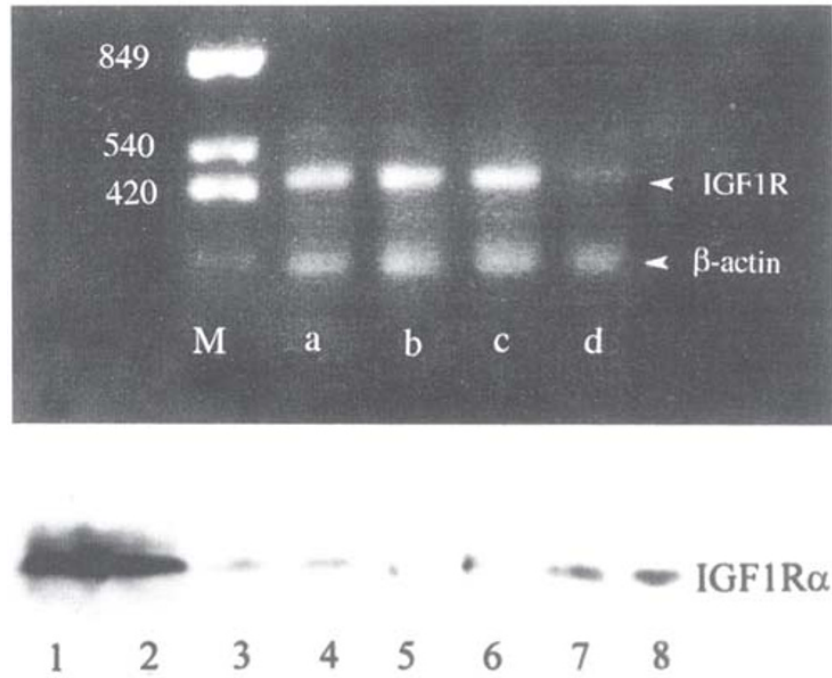

Fig 5. Representative example of IGF1R mRNA and protein expression of T24 cells after being treated with antisense ODN for $72 \mathrm{~h}$ Three different experiments were done in duplicate to obtain means and SD. $\beta$-actin level remained stable in each group. (A) Effect of antisense ODN on IGF1R mRNAs expression of T24 cells. M: marker (bp). Lane 1: positive control K562 cells. Lane 2: IGF1R sense ODN (10 $\mu \mathrm{M})$ treated T24 cells. Lane 3: untreated T24 cells. Lane 4: IGF1R antisense ODN $(10 \mu \mathrm{M})$ treated T24 cells. (B) Effects of antisense ODN on IGF1R protein expression of T24 cells Lane 1, 2: untreated T24 cells Lane 3, 4: $5 \mu \mathrm{M}$ antisense ODN treated T24 cells Lane 5, 6: $10 \mu \mathrm{M}$ antisense ODN treated T24 cells Lane 7, 8: K562 cells used as positive control 
We first examined the effect of antisense ODN targeting against IGF-1R gene on its mRNA and protein expression. Representative data was shown in Fig 5. Relative expression intensities of IGF-1R gene to b-actin gene (Fig 5A) and the expression intensities of IGF-1R protein (Fig 5B) were quantified by densitometric scanning. The values rep-

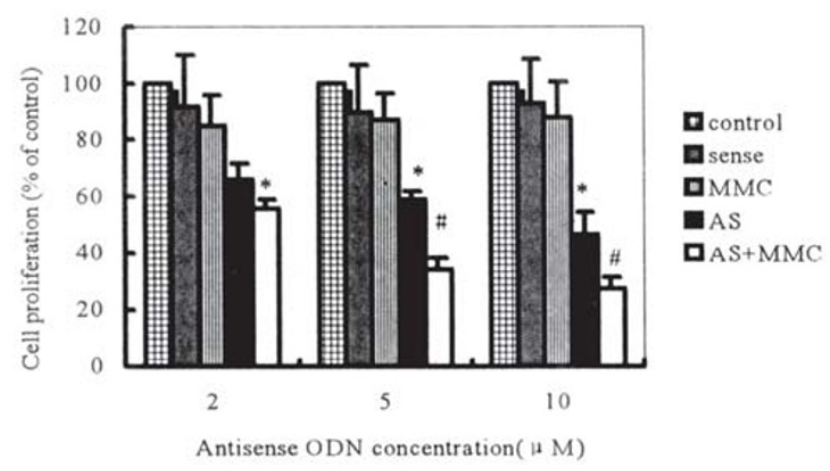

Fig 6. Effect of antisense ODN at different concentrations on drug sensitivity of T24 to MMC The data are the mean \pm standard deviation from a representative experiment performed in triplicate. Very similar data were obtained in an additional experiment. Results are expressed as proliferation percentage of respective untreated control. AS: antisense ODN; Sense: sense ODN. " $\mathrm{P}<0.05$ as compared with respective control group. ${ }^{\#} \mathrm{P}<0.01$ as compared with respective control group and ${ }^{\#} \mathrm{P}<: 0.05$ as verse MMC group.

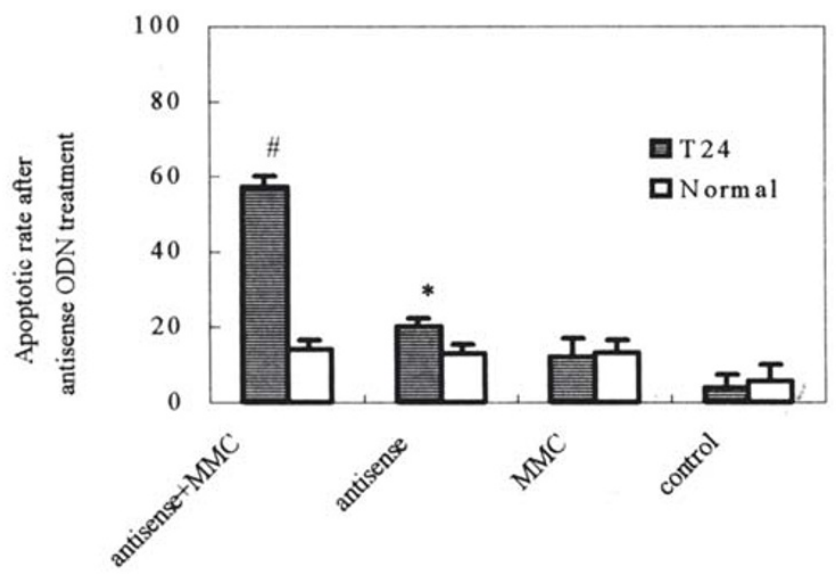

Fig 7. Effect of antisense ODN specific for IGF1R gene on apoptosis of T24 cells induced by MMC The results were obtained from a representative experiment performed in triplicate. Very similar results were obtained in an additional experiment. T24 control was MMC- and antisense- untreated group. Concentration of MMC used here was $0.2 \mu \mathrm{M}$. Normal: Normal urothelial cells ${ }^{*} \mathrm{P}<0.05$ as compared with $\mathrm{T} 24$ control group ${ }^{\#} \mathrm{P}$ $<0.01$ as compared with T24 control group and ${ }^{\#} \mathrm{P}<0.05$ as versus MMC group resented mean \pm S.D of three different experiments performed in duplicate. The relative mRNA expression in K562 positive control group was $1.42 \pm 0$. 19. The relative expression of IGF-1R mRNA in antisense untreated group was $1.37 \pm 0.17$. After the treatment with antisense ODN $(10 \mu \mathrm{M})$ specific for IGF-1R gene, the relative intrinsic mRNA expression of IGF-1R gene was $0.37 \pm 0.07$ and was reduced approximately $74 \%$ compared with antisense ODN untreated T24 group $(\mathrm{P}<0.001)$ The values of protein expression were as follows:

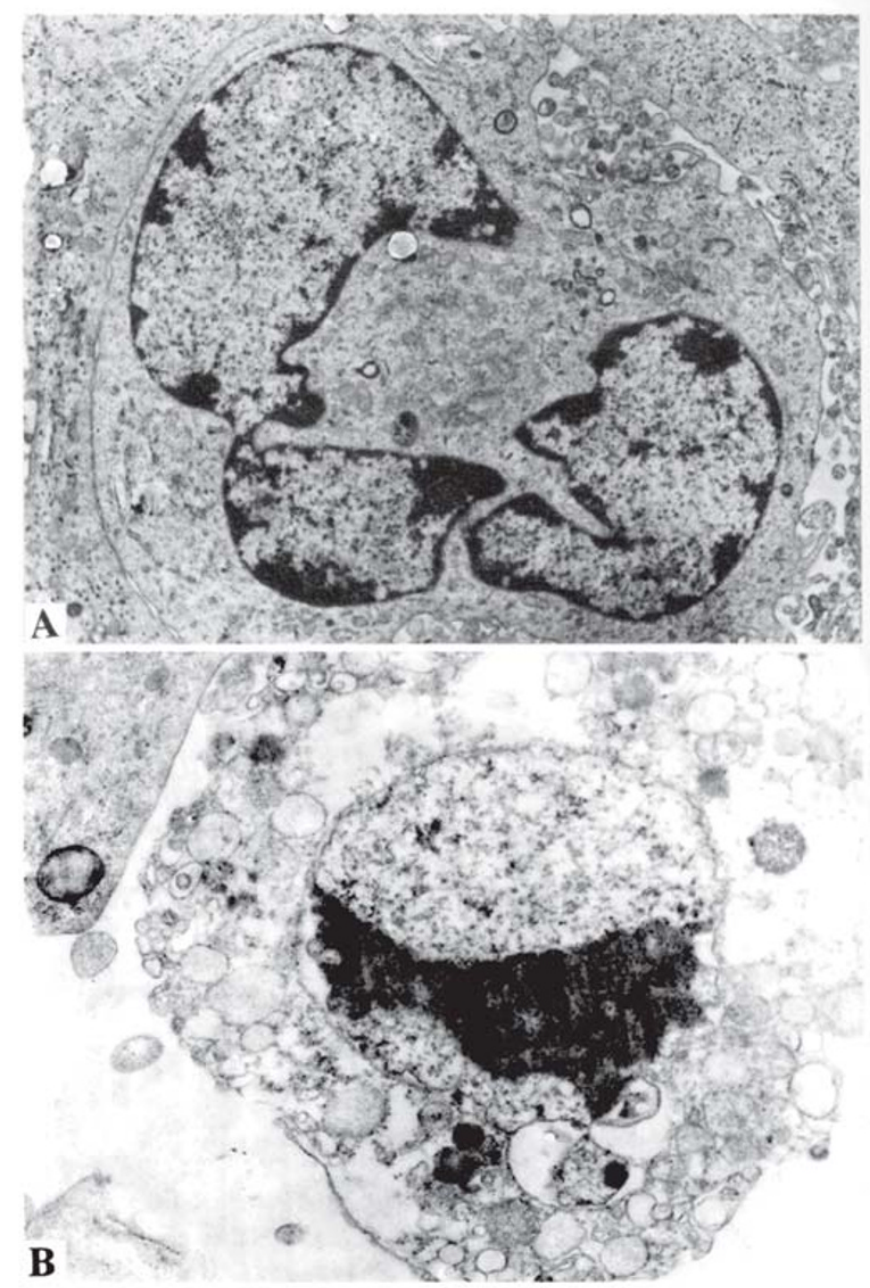

Fig 8. Examination by electron microscopic study after blockage of IGF1R signaling by antisense ODN for $72 \mathrm{~h}$ The results were obtained from three different experiments performed in duplicate. After being treated with antisense ODN, T24 cells showed the morphological changes of apoptosis: the chromatin of T24 cells became condensed and appeared vacuolization of cytoplasm with regular crescent shaped structure.
(A) Antisense ODN-untreated T24 cells
(B) Antisense ODN

$(10 \mu \mathrm{M})$ treated T24 cells 
$1614 \pm 156$ (antisense ODN untreated T24 group), $621 \pm 27(5 \mu \mathrm{M}$ antisense ODN treated T24 cells), $276 \pm 186(10 \mu \mathrm{M}$ antisense ODN treated T24 cells). The protein synthesis of IGF1R was downregulated by $61.3 \%(\mathrm{P}<0.001,5 \mu \mathrm{M}$ antisense ODN treated) and 77\% $(\mathrm{P}<0.001,10$ $\mu \mathrm{M}$ antisense ODN treated) respectively. Taken together, these data showed antisense ODN could effectively reduce the mRNA and protein expression of IGF-1R gene.

We then examined the effect of antisense ODN on drug sensitivity of T24 to MMC. As shown in Fig 6, treatment of T24 cells with IGF-1R antisense ODN for $72 \mathrm{~h}$ enhanced the sensitivity of T24 cells to $0.2 \mu \mathrm{M} \mathrm{MMC}$. Apoptotic analysis by flowcytometry also confirmed that blocking IGF-1R signali antis ense ODN could cause targeted cells to be more sensitive to MMC induced apoptosis (as shown in Fig 7). And further examination by electron microscopic study was also consistent with the observed apoptosis after blockage of IGF-1R signaling by antisense ODN (Fig 8)

\section{DISCUSSION}

Bladder cancer is the most common urologic malignancy. On histopathology, 93\% of bladder cancers are transitional cell carcinomas. The majority of bladder cancers are superficial cancers (80\%). Patients with low-risk characteristics are managed by transurethral resection (TUR) alone. Intravesical chemotherapy plays a very important role in the treatment of superficial bladder cancer after TUR. The ability to predict the sensitivity of individual human TCC tumors to the effects of anticancer agents would rationalize current prescribing policy and could affect the clinical response of TCC to intravesical therapy[30]. The first-line intravesical chemtherapeutic agent for superficial bladder cancer is mitomycin C (MMC). Studies confirmed the beneficial effect of a single instillation of mitomycin $\mathrm{C}$ after TUR. The mechanism of action of MMC is largely attributable to its cross-linking with DNA, particularly at guanine/cytosine-rich regions. The drug is most effective when given in the late G1 and early S phases of the cell cycle. $\mathrm{MMC}$ is clinically used in does ranging from 20-60 $\mathrm{mg}$ in each treatment once a week[31].

Ruck A et al have previously shown that human bladder cancer cell lines may be adapted to grow in the complete absence of serum or any other growth supplement and this could be explained on the basis of autocrine stimulation[32]. The acquirement of autonomous growth capacity was likely to be an important element in the oncogenesis of bladder cancer[33]. Furthermore, criss-cross experiments showed that supernatants of the autologous cell line of bladder cancer not only stimulated the proliferation of its own cells, but also the growth of other bladder cancer cell lines, which suggested the production of common autocrine growth factors for bladder cancer cells[28]. Some factors or their receptors involved in autocrine loop mechanism of bladder cancer cells have been confirmed, such as IL-6, EGFR, IFN- $\beta$, transferrins-like substance etc[34],[35]. But more other unknown factors which may play key roles in autocrine mechanisms of TCCs need to be further characterized.

The previous studies carried out have identified the high expression level of IGF-1R in bladder tumor tissue[6],[19]. Some of the present study yielded the following conclusions: (1) The mRNAs of IGF-1, IGF-2 and IGF-1R were strongly expressed in serum-free cultured T24 cells, whereas normal urothelial cells did not express these factors/receptors or only in trace levels; (2) bladder cancer cells responded far better to growth stimulation by IGF-1 than did normal urothelial cells; (3) growth of bladder cancer cells was significantly inhibited by the addition of antisense ODN specific for IGF-1R cDNA. These results suggested the autocrine role of IGF1R signaling in bladder carcinoma cells but not in the normal urothelial cells. Our observations indicated a possible mechanism by which TCCs acquired an additional growth advantage over their benign counterparts: namely, by the acquisition of a better response to IGF-1 and of the ability to synthesize and secrete IGFs.

This study also presented evidences on the biologic role of both anti-apoptosis and drug resistance by IGF-1 signaling in the human T24 bladder cancer cells. The findings that growth stimulation and drug resistance mediated by exogenous IGF-1 activated anti-apoptotic events in T24 cells, which demonstrated that IGF-1 could elicit T24 cells drug resistance to chemotherapeutic agents. Moreover, the addition of IGF-1R antisense ODN inhibited cell 
growth and cell survival, confirming the positive role of endogenous, self-secreted IGFs in cell survival. Furthermore, synergy with antisense ODN was achieved with very low concentrations of MMC agent (Fig 7), thus minimizing their toxicity and maximizing their therapeutic application in vitro. Studies on the function of IGF-1R follow one topic: IGF-1R plays crucial role in the mechanism of anti-apoptosis[8],[9]. In this study, “knockdown" of IGF-1R by antisense ODN can significantly enhance apoptotic sensitivity of T24 cells to MMC, which was consistent with this hypothesis about the involvement of IGF-1R in apoptosis. Altogether, these findings suggested that IGF-1R signaling pathway may serve as potential candidates for clinical intervention in the sensitization of drug-resistant bladder carcinoma cells to cytotoxic drugs.

Here, we would like to evaluate the potential therapeutic application of antisense ODN targeted against IGF-1R gene on urinary bladder cancer cells. It should be pointed out: (1) Targeting the IGF-1R is more efficient than targeting its ligands because targeting one ligand leaves other one free to activate the IGF-1R[8]. (2) The bladder is particularly amenable to such experimental treatment, because its special anatomic structure and localized therapy is possible by intravascular administration, thus minimizing side effects[20]. (3) It has shown that antisense ODN against IGF-1R gene is remarkably non-toxic in vivo[7].

In summary, we concluded that acquisition of IGFs-producing capability and of a better response to IGF-1 may be a common manifestation of bladder cancer and may give a growth advantage over non-neoplastic urothelial cells. Further antisense blockage of IGF-1R signaling could augment TCCs sensitivity to MMC, indicating potential clinical application of IGF-1R antisense ODN for bladder cancers. Nevertheless, these various approaches await appropriate preclinical in vivo studies to delineate their effect and toxicity.

\section{REFERENCES}

[1] Davies JM, Occupational and environmental factors in bladder cancer. In Scientific Foundation of Urology, Heinemanm London, Indedn 1992:723-7.

[2] Bindels M, Vermey M, Rebel J.M, Zwarthoff EC, VanDer-Kwast TH. In vitro modulation of implantation and intraepithelial expansion of bladder tumor cells by epidermal growth factor. Exp Cell Res 1997; 235:395402.

[3] Nakagawa M, Emoto A, Nasu N, Nomura Y. Clinical significance of multi-drug resistance associated protein and P-glycoprotein in patients with bladder cancer. The Journal of Urology 1997; 157:1260-5.

[4] Borsellino N, Nonavida B, Ciliberto G, Toniatti C, Travali S, D'Alessandro N. Blocking signaling through the GP130 receptor chain by interleukin-6 and oncostatin inhibits PC-3 cell growth and sensitizes the tumor cells to Etoposide and cisplatin-mediated cytotoxicity. Cancer 1999; 85:134-44.

[5] Dunn SE, Hardman RA, Kari FW, Insulin-like growth factor (IGF-1) alters drug sensitivity of HBL100 human-breast cancer cells by inhibition of apoptosis induced by diverse anticancer drugs. Cancer Res 1997; 57: 2687-93.

[6] Torrisi R, Mezzetti M, Johannson H, Decensi A. Time course of fenretinide-induced modulation of circulating insulin-like growth factor 1, IGF-2 and IGFBP in a bladder cancer chemoprevention trial. Int $\mathrm{C}$ Cancer 2000; 87: 601-5. [7] Blakesley VA, Stannard BS, Kalebic T, Helman LJ, Roith D. Role of IGF-1 receptor in mutagenesis and tumor promotion. Journal of Endocrinology 1997; 152:339-44.

[8] Baserga R, Hongo A, Rubini M, Pvisco M, Valentinis B. The IGF-1 receptor in cell growth, transformation and apoptosis. Biochimica et Biophysica Acta 1997; 1332: F105-26.

[9] Baserga R. The IGF-1 receptor in cancer research. Experimental Cell Research 1999; 253:1-6.

[10] Alessandro ND. Biology versus pharmacology in drug resistance. Oncol Rep 1997; Supple:207-10.

[11] Xu F, Garder A, Tu Y. Multiple myeloma cells are protected against dexamethasone-induced apoptosis by insulin-like growth factors. Bri-J-Haematol 1997; 97: 429-40.

[12] Singleton JR, Dixit VM, Feldman EL. Type1 insulinlike growth factor receptor activation regulates apoptotic proteins. J Biol Chem 1996; 27:31771-4.

[13] Parrizas M, LeRoith D. Insulin-like growth factor 1 inhibition of apoptosis is associated with increased expression of the bcl-XL gene product. Endocrinology 1997; 138:1355-8.

[14] Anderson P. Kinase cascades regulating entry into apoptosis. Microbiology and molecular Biology Reviews 1997; 16:33-46.

[15] Cote R.J, Esrig D, Groshem S. P53 and treatment of bladder cancer. Nature 1997; 385:123.

[16] Fadeel B, Hassan Z, Hellstrom-Lindberg E, Henter JI, Orrenius S, Zhivotovaky B. Cleavage of Bcl-2 is an early event in chemotherapy-induced apoptosis of human myeloid leukemia cells. Leukemia 1999; 13:719-28.

[17] Huo Y, Jin G, Houston CW, Thompson JC, Townsend JR. Insulin-like growth factor-1 promotes multidrug resistance in MCLM colon cancer cells. Journal of Cellular Physiology 1998; 175:141-8.

[18] Iwanura M, Ishibe M, Sluss PM. Characterization of 
insulin-like growth factor 1 binding sites in human bladder cancer cells lines. Urol. Res. 1993; 21:27-32.

[19] Cooper MJ, Fischer M, Komitowski D, Shevelev A, Schulze E, Ariel I. Developmentally imprinted genes as markers for bladder tumor progression. The Journal of Urology 1996; 155:2120-7.

[20] Sandra ED, Frank WK, John F, Joel RL, Barrett JC. Dietary Restriction reduces insulin-like growth factor 1 levels, which modulates apoptosis, cell proliferation, and tumor progression in p53-deficient mice. Cancer Research 1997; 57:4667-72.

[21] Hasegawa S, Abe T, Naito S, Kotoh S, Kumazawa J. Expression of multidrug resistance-associated protein (MRP), MDR1 and DNA topoisomerase 2 in human multi-drug-resistant bladder cancer cell line. British Journal of Cancer 1995; 71:907-13.

[22] Reznikoff CA, Johnson MD, Nobhack DH, Bryan GT. Growth and characterization of normal human urothelium in vitro. In Vitro 1983; 19:326-43.

[23] Ulirich A, Gray A, Tam A. Insulin-like growth factor 1 receptor primary struture: comparison with insulin receptor suggests structural determinants that define functional specificity. EMBO J 1986; 5:2503-12.

[24] Sussenback JS, The gene structure of the insulin-like growth factor family. Prog Growth Factor Res 1989; 1: 33-8.

[25] Pagter-Holthuizen PD, Van Schaik FM, Verduijn GM. Organization of the genes for insulin-like growth factor 1 and 2. FEBS lett 1986; 195:2503-12.

[26] CHANG Yunchao, Xu Yonghua. Expression of Bcl-2 inhibited Fas-mediated apoptosis in human hepatocellular carcinoma BEL-7404 cells. Cell Research 2000;
10:233-42.

[27] Resnicoff M, Coppola D, Sell C, Rubin R, Ferrone S. Growth inhibition of human melanoma cells in nude mice by antisense strategies to the Type 1 insulin-like growth factor receptor. Cancer Research 1994; 54:484850.,p.

[28] Singh SV, Scalamogna D, Hong X, O'TooLE S, Emerson EO. Biochemical characterization of a mitomycin $\mathrm{C}$ resistant human bladder cancer cell line. Int J Cancer 1996; 65:852-7.,p.

[29] Ruck A, Paulie S. The epidermal growth factor receptor is involved in autocrine growth of human bladder carcinoma cell lines. Anticancer Res 1997; 17:1925-31.

[30] Pow-Sang JM, Seigne JD. Contemporary Management of Superficial Bladder Cancer. Cancer Control 2000; 4: 335-9.

[31] Kelly JD, Williamson HP, Johnston SR. Induction of apoptosis by mitomycin-C in an ex vivo model of bladder cancer. BJU International 2000; 85:911-7

[32] Ruck A, Takobson E, Bjorkman S, Paulie S. Adaptation of human bladder carcinoma cell lines to serum-free growth: Evidence for autocrine growth stimulation. Anticancer Res 1994; 14:55-60.

[33] Otto T, Bex A, Schmidt U, Ral A, Rubben H. Improved prognosis assessment for patients with bladder carcinoma. Am J Pathol 1997; 150:1919-23.

[34] Tanoquchi H, Tachibana M, Murai M. Autocrine growth induced by tranferrin-like substance in bladder carcinoma cells. Br J Cancer 1997; 76:1262-70.

[35] Okamoto M, Hattori K, Oyasu R. Interleukin-6 function as an autocrine growth factor in human bladder carcinoma cell lines. In J Cancer 1997; 72:149-54. 